\title{
Association of endothelial nitric oxide synthase gene variants with preeclampsia
}

\author{
Ghazala Shaheen ${ }^{1}$, Sarwat Jahan ${ }^{1}$, Nousheen Bibi $^{2}$, Asmat Ullah ${ }^{4}$, Rani Faryall ${ }^{5}$, Ali Almajwal ${ }^{3}$, Tayyaba Afsar ${ }^{3}$, \\ Dara Al-disi ${ }^{3}$, Mahmoud Abulmeaty ${ }^{3}$, Abdulaziz Abdullah Al Khuraif ${ }^{6}$, Mohammed Arshad ${ }^{6}$ and Suhail Razak ${ }^{3^{*}}$
}

\begin{abstract}
Background: Preeclampsia (PE) is a complex pregnancy hypertensive disorder with multifaceted etiology. The endothelial nitric oxide synthase (eNOS) gene and nitric oxide (NO) levels has been reported to be associated with PE predisposition in various populations. Therefore, present study was designed to investigate the role of NO levels and eNOS gene variants in preeclamptic women in Pakistan.

Methods: A total of 600 women were evaluated, 188 of PE with mild features, 112 of PE with severe features and 300 normotensive pregnant women. NO levels were detected by Greiss reaction method and genotyping following sequencing was conducted for eNOS gene variants. Further insilico studies were performed to get insights into the structural and functional impact of identifies mutation on eNOS protein as well as on protein regulation.
\end{abstract}

Results: Reduced concentrations of NO were reported in all PE groups $(p<0.05)$ as compared to controls. The frequency of c.894 T (p.298Asp) and g.-786C alleles were significantly associated with PE. In addition, novel homozygous variant g.2051G > A was also significantly associated with PE when compared to normotensive women. Dynamic simulation studies revealed that Glu298Asp mutation destabilize the protein molecule and decrease the overall stability of eNOS protein. Molecular docking analysis of mutant promoter with transcription factors STAT3 and STAT6 proposed changes in protein regulation upon these reported mutations in upstream region of the gene.

Conclusion: Considering the results of current study, the functional alterations induced by these variants may influence the bioavailability of $\mathrm{NO}$ and represents a genetic risk factor for increased susceptibility to PE. However, large studies or meta-analysis are necessary to validate these findings.

\section{Plain Language Summary}

Preeclampsia (PE) is a complex pregnancy hypertensive disorder with multifaceted etiology characterized by increased hypertension and proteinuria after 20 weeks of gestation. The present study was directed to determine the role of eNOS in susceptibility to PE and the association of c.894G > T (p.(Glu298Asp), intron 4b/4a, g.-786 T >C and other possible variants of eNOS gene with preeclampsia in Pakistani population. Computational analysis of identified variants in the coding and non-coding region of the eNOS gene was also conducted to determine the change in gene regulation and further protein stability. A total of 600 women were evaluated, 188 with mild and 112 with PE with severe features PE with 300 normotensive pregnant women. NO levels and genotyping following sequencing was conducted for eNOS gene variants. Further insilico studies were performed to get insights into the structural

\footnotetext{
*Correspondence: smarazi@ksu.edu.sa

${ }^{3}$ College of Applied Medical Sciences, Community Health Sciences, King

Saud University, Riyadh, Kingdom of Saudi Arabia

Full list of author information is available at the end of the article
}

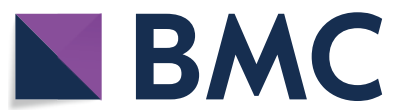

(c) The Author(s) 2021. Open Access This article is licensed under a Creative Commons Attribution 4.0 International License, which permits use, sharing, adaptation, distribution and reproduction in any medium or format, as long as you give appropriate credit to the original author(s) and the source, provide a link to the Creative Commons licence, and indicate if changes were made. The images or other third party material in this article are included in the article's Creative Commons licence, unless indicated otherwise in a credit line to the material. If material is not included in the article's Creative Commons licence and your intended use is not permitted by statutory regulation or exceeds the permitted use, you will need to obtain permission directly from the copyright holder. To view a copy of this licence, visit http://creativecommons.org/licenses/by/4.0/. The Creative Commons Public Domain Dedication waiver (http://creativeco mmons.org/publicdomain/zero/1.0/) applies to the data made available in this article, unless otherwise stated in a credit line to the data. 
and functional impact of identifies mutation on eNOS protein as well as on protein regulation. Data from the current study suggest that there might be other risk variants of the eNOS gene (g.2051G $>$ A and g.1861G $>$ A) and lower levels of serum NO that confers in an increased risk of PE. The detailed computational investigation further confirmed the deformities and changes in protein flexibility upon Glu298Asp. These structural alterations might be associated with preeclampsia. Variants in the promoter region of the eNOS gene further validate the change in gene regulation for the onset of disease. Identification of key structural and functional features in eNOS protein and gene regulatory region might be used for designing specific drugs for therapeutic purpose.

Keywords: Preeclampsia, Endothelial nitric oxide synthase gene, Nitric oxide, Variants

\section{Background}

Preeclampsia (PE) is a complex pregnancy hypertensive disorder with multifaceted etiology characterized by de novo hypertension, with or without proteinuria, accompanied with the signs of maternal acute kidney injury (AKI), neurological features, liver dysfunction, hemolysis or thrombocytopenia, or fetal growth restriction after 20 weeks of gestation [1-3]. It is the leading cause of maternal and prenatal morbidity and mortality in developing countries [4]. Annually 63,000 maternal and 50,000 infant's deaths are predicted to be associated with PE [57]. Prevalence of PE is higher in developing countries like Pakistan where PE and eclampsia was around $19 \%$ and 1 in 89 women dies of maternal causes [8,9]. Studies have shown various factors involved in the susceptibility of $\mathrm{PE}$, but etiological details are still being debated [10]. Pathogenesis of $\mathrm{PE}$ is multifactorial involving environmental and genetic factors [11]. It was determined that defective placentation is associated with the progression of $\mathrm{PE}$ [12]. Disturbed trophoblastic invasion and spiral arteries remodeling results in endothelial dysfunction which leads to vasoconstriction [11].

Various mediators are involved in controlling endothelial dysfunction in PE but the role of endothelial nitric oxide synthase $(e N O S)$ gene located at the $7 \mathrm{q} 35-\mathrm{q} 36$ region appears most significant in the development of $\mathrm{PE}$ [13]. eNOS is an important regulator of vascular tone and contributes to the reduction of the uteroplacental resistance seen in normal pregnancy through the production of Nitric Oxide (NO) by reduction of L-arginine to L-citruline [14]. Polymorphisms of eNOS impair NO availability which is crucial for maternal vascular vasodilation during pregnancy, leading to susceptibility of PE $[15,16]$.

Several variants in $e N O S$ gene were identified effecting its functions or production levels (Rahimi et al., 2013). These variants comprise of functional c.894G $>\mathrm{T}$ (p.(Glu298Asp)) variant in exon 7 of $e N O S$ gene.[16-19], an insertion-deletion variant in intron $4(4 \mathrm{~b} / 4 \mathrm{a})$ consisting of $27 \mathrm{bp}$ tendem repeats, $4 \mathrm{~b}$ allele comprises of 5 repeats and 4 a allele with 4 repeats $[4,10,20]$ and g.-786 T >C variant present in promotor region of $e N O S$ gene $[1,15,21]$.
Considering the potent role of polymorphism in the eNOS gene in causing clinical symptoms of PE different mega projects and meta-analysis were conducted to better understand the underlying mechanisms but there are many gaps to be filled [22]. Under a detailed study projected towards this important issue related to maternal health, for the first time the role of $e N O S$ gene in PE was highlighted in Pakistan. The present study was directed to determine the role of eNOS in susceptibility to PE and the association of c.894G $>\mathrm{T}$ (p.(Glu298Asp), intron 4b/4a, g.-786 T>C and other possible variants of $e N O S$ gene with $\mathrm{PE}$ in Pakistani population. Computational analysis of identified variants in the coding and non-coding region of the eNOS gene was also conducted to determine the change in gene regulation and further protein stability (Additional file 1).

\section{Methods \\ Compliance}

The present study was conducted with prior approval from ethical committees of Quaid-i-Azam University, Islamabad (BEC-FBS-QAU2015-98) and collaborating hospitals including Pakistan Institute of Medical Sciences (PIMS) (F.1-1/2015/ERB/SSZABMU), Islamabad and Quaid-e-Azam International Hospital, Islamabad (QAIH-2015/11). All participants were informed about the study objectives and signed an informed consent. The study protocol was done in accordance with the principles of the Declaration of Helsinki.

\section{Participants}

The studied individuals comprised of 300 pregnant women with preeclampsia including 188 with mild features and 112 with severe features and 300 normotensive pregnant women as controls which were recruited at Pakistan Institute of Medical Sciences (PIMS) and Quaid-e-Azam International Hospital, Islamabad during the period of September 2015 to July 2017. These are the important hospitals in the capital territory of Pakistan where patients visit from different rural and urban areas and they provide the quality health services with personalized and specialized care for patients. According to the 
hospital staff 1 in 10 pregnant women is diagnosed with hypertension which also include PE. That's why prominent number of deliveries occur in the respective hospitals. All women included were $<35$ years of age. Informed consent and a detailed Performa (including history and clinical examination) were filled before sample collection. Blood pressure of all study subjects was measured by sphygmomanometer in millimeters of mercury $(\mathrm{mmHg})$.

\section{Inclusion and exclusion criteria}

The control group have women with uncomplicated gestation and blood pressure $<125 / 85 \mathrm{mmHg}$ and no proteinuria. Diagnostic criteria for $\mathrm{PE}$ with mild features was blood pressure $\geq 140 / 90 \mathrm{mmHg}$, and proteinuria $\geq+1$ on Dipstick test. PE with severe features was defined as blood pressure $\geq 160 / 110 \mathrm{mmHg}$, and proteinuria (proteinuria $\geq+3$ on Dipstick test [23]. Exclusion criteria involved diabetes, asthma, kidney disease, hematological disorder, autoimmune disease, current or history of smoking and eclampsia.

\section{Sampling and storage}

Blood was collected during the antepartum period (third semester, $36.32 \pm 0.36$ weeks for controls $33.14 \pm 0.48$ for PE with mild features, $33.08 \pm 0.56$ for PE with severe features and $33.12 \pm 0.15$ for total PE group) before the onset of delivery in labelled tubes for clinical investigations and genetic analysis. Blood samples were divided into two parts, serum was separated immediately by centrifugation at $3000 \mathrm{rpm}$ for $10 \mathrm{~min}$ from half of the blood in non-EDTA tubes and stored at $-80{ }^{\circ} \mathrm{C}$ for estimation of NO, while second part present in EDTA tubes was stored at $-4{ }^{\circ} \mathrm{C}$ for DNA extraction, genotyping and sequencing.

\section{Genetic analysis}

DNA was extracted from blood using GF-1 Blood DNA Extraction Kit (Vivantis Technology, USA) according to manufacturer's instruction. Primers (humanizing genomics macrogen, Korea) were selected from the previous study [24]. c.894G > T (p.(Glu298Asp) (rs1799983) variant in exon 7 of the eNOS gene was detected by Polymerase chain reaction (PCR) (Maxygene Thermal Cycler 230v, TWN) using the forward primer of 5'-CAT GAGGCTCAGCCCCAGAAC- $3^{\prime}$ and reverse primer of 5'-AGTCAATCCCTTTGGTGCTCAC-3'. After amplification the PCR product was digested using $5 \mathrm{U}$ MboI restriction endonuclease enzyme (Cat\#ER0811 Thermo Scientific, USA) by overnight incubation at $37^{\circ} \mathrm{C}$. Genotypes were determined by separation of fragments on $2 \%$ agarose gel.

Intron 4b/4a (rs1722009) allele was detected by PCR method using a forward primer of 5'-AGGCCCTATGGT
AGTGCCTTG-3' and reverse primer of $5^{\prime}$-TCTCTT AGTGCTGTGGTCAC-3'. The PCR product was electrophoresed on $2.5 \%$ agarose gel.

g.-786 T > C (rs2070744) variant in promoter region of eNOS gene was detected by Tetra ARMS-PCR method using an outer forward primer of $5^{\prime}$-TTTCTCCAGCCC CTCAGATG-3' and outer reverse primer of $5^{\prime}$-AGG CCCAGCAAGGATGTAGT-3', while inner primer for $\mathrm{C}$ allele was 5'-CATCAAGCTCTTCCCTGGCC-3' and inner primer for $\mathrm{T}$ allele was 5'-CATCAAGCTCTTCCC TGGCT-3' respectively. The target gene was amplified, the double reaction was conducted for each sample with respective inner allele primer and the PCR product was subjected to $2 \%$ agarose gel electrophoresis. For the confirmation of these variants and other new variants in the respective regions Sanger sequencing was performed (DTCS Quick Start Kit; Beckman Coulter, Fullerton, CA, USA).

\section{Estimation of NO}

Nitric oxide (NO) decomposes from nitrite $\left(\mathrm{NO}_{2}{ }^{-}\right)$and nitrate $\left(\mathrm{NO}_{3}{ }^{-}\right)$. Nitrite is the stable end product and estimated as an index of NO by using Greiss reaction. For the quantitative determination of NO, total NO kit (Cat\# EMSNO, Thermo Scientific, USA) was used according to the manufacturer's instruction in which enzyme nitrate reductase converts nitrate to nitrite. Nitrite is then detected as a colored azo dye product of the Griess reaction that absorbs visible light at $540 \mathrm{~nm}$. The interaction of $\mathrm{NO}$ in a system was measured by the determination of total nitrate and nitrite concentrations in the sample.

\section{Computational analysis}

In silico site directed mutagenesis of eNOS protein

The 3D structure of mutant (eNOS $\left.{ }^{\mathrm{Glu} 298 \mathrm{Asp}}\right)$ protein was built in Chimera using normal eNOS protein 3D structure (PDBID: 1m9q) as template. The stereochemical properties and environmental profile of the mutant model was evaluated using PROCHECK [25] and ERRAT (Structure analysis and verification servers) respectively. Mutant model was minimized using Chimera 1.5.6 [26] and NOMAD-Ref (http://lorentz.immstr.pasteur.fr/ nomad-ref.php) further the root-mean-square deviation (RMSD) of native and mutant structure was also calculated.

\section{Molecular dynamic simulations}

Molecular dynamic (MD) simulations studies were of $e N O S^{\mathrm{WT}}$ and mutant $e N O S^{\text {Glu298Asp }}$ were made to assess the folding, stability, conformational changes and dynamic behaviors of eNOS3 protein. Amber03 force field embedded in GROMACS 4.5 package [27] running on high performance OpenSuse linux system was 
used to perform simulations. Throughout simulations experiments, both eNOS3 ${ }^{\mathrm{WT}}$ and mutant $e N O S^{\mathrm{Glu} 298 \mathrm{Asp}}$ systems were solvated by TIP4P [28] water model in a periodic box. The system was neutralized by addition of $\mathrm{Na}^{+}$and $\mathrm{Cl}^{-}$counter ions. Energy minimization (steepest descent algorithm for 500 steps) was executed by the tolerance of $1000 \mathrm{~kJ} / \mathrm{mol} \AA^{2}$ to eliminate initial steric clashes. After completing the minimization steps systems were subjected to simulations for $20 \mathrm{~ns}$ time scale under constant temperature $(300 \mathrm{~K})$ and pressure $(1 \mathrm{~atm})$. To this end electrostatic interactions were calculated using Particle Mesh Ewald (PME) algorithm. To investigate the stability behavior of $e N O S^{\mathrm{WT}}$ and mutant $e N O S^{\text {Glu298Asp }}$ systems, VMD [29], PyMol (http://www.pymol.org) and GROMACS tools were used.

\section{Transcription factor binding site prediction in the promoter region}

Transcription factors are key to the regulation of genes and form the basis of gene regulation studies and understanding of gene on and off mechanism. ConTraV3 (http://bioit2.irc.ugent.be/contra/v3) and JASPER database were used for the prediction of transcription factor binding site in the promoter region of eNOS gene.

\section{DNA model building}

DNA model was generated for promoter region with three sequences (Seq1: CCCTCAGATGGCACAGAA CTAC, Seq2: CTTCCCTGGCTGGCTGACCCTG, Seq3: CCCGGGAAGCGTGCGTCACTG) of eNOS Nucleic Acid Builder (NAB) program [30, 31] and 3D-Dart server [32]. All the generated models were minimized for phosphate backbone geometry optimization.

\section{Protein DNA molecular docking}

Protein-DNA interactions are key to in several biological processes, DNA repair, gene regulation and chromatin structural organization. DOT 2.0 program suite [33] (http://www.sdsc.edu/CCMS/DOT) was used to calculate the potential binding site and binding energies of the promoter region of $e N O S$ and its putative transcription factor protein. Grid was set large enough for smooth movement of molecule around the stationary molecule. Additionally, at the grid boundaries stationary potential was near zero to reduce the artifacts from fast Fourier calculations. In present docking experiments rotational sets of $28,800\left(7.5^{\circ}\right)$ and $54,000\left(6^{\circ}\right)$ were used.

\section{Statistical analysis}

All data were expressed as mean \pm S.E.M (standard error of the mean). Statistical analysis for NO levels was carried out by using lme4 [34] and easyanova [35] package of R 3.5.1 (R Development Core Team, 2018) and NO concentrations were compared with age, gestational age and BMI by analysis of variance. The difference between groups was analyzed by ANOVA eal command and graph was obtained by ggboxplot command in ggpubr package of R. Statistical analysis of clinical data and the frequency of alleles and genotypes were compared between study and control group by Independent sample t test, Chi-squared test $\left(\chi^{2}\right)$ and Odds Ratio (OR) with values predicted by Hardy-Weinberg equilibrium model and linear regression by using IBM SPSS Statistics 21 software. Values of $\mathrm{p}<0.05$ were considered statistically significant.

\section{Results}

\section{Characteristics of study individuals}

The characteristics of cases and controls at diagnosis are shown in Table 1. The significant difference was noted between control and preeclamptic groups with regard to age $(\mathrm{p} \leq 0.001$ and $\mathrm{p}=0.002)$, body mass index (BMI) $(\mathrm{p} \leq 0.001$ and $\mathrm{p}=0.047)$, systolic and diastolic blood pressure $(\mathrm{p} \leq 0.001)$, Gestational age $(\mathrm{p} \leq 0.001)$, proteins in urine $(\mathrm{p} \leq 0.001)$ and child weight at birth $(\mathrm{p} \leq 0.001)$. Furthermore, the family history of preeclampsia and preeclampsia in previous pregnancy and in primigravida was more prominent in the preeclamptic groups as compared to normotensive females (Table 2).

\section{Estimation of NO}

Serum NO levels were estimated in all study groups comparable with normotensive healthy controls and difference between them was significant $(\mathrm{F}=4.87, \mathrm{P}=0.003)$. Significantly low levels of NO were observed in PE with mild features $(50.18 \pm 2.78, \mathrm{P}=0.003)$, $\mathrm{PE}$ with severe features $(48.59 \pm 3.68, \mathrm{P}=0.02)$ and total preeclamptic group $(49.6 \pm 2.22, \mathrm{p}=0.002)$ as compared to control group (62.12 \pm 2.88$)$ (Fig. 1). When NO levels were compared to age, gestational age and BMI the results were non-significant with $\mathrm{p}$ value of $0.14,0.52$ and 0.40 .

\section{eNOS variants distribution}

The distribution of eNOS c.894G > T (p.(Glu298Asp)), intron $4 \mathrm{~b} / 4 \mathrm{a}$ and g.-786 $\mathrm{T}>\mathrm{C}$ variants were studied in all groups as presented in Table 3, Fig. 2. The genotypic distribution was in Hardy-Weinberg equilibrium. For c.894G $>\mathrm{T}$ (p.(Glu298Asp)) variant electrophoresis of digested product yield band sizes of $206 \mathrm{bp}$ for GG, $206 \mathrm{bp} / 119 \mathrm{bp} / 87 \mathrm{bp}$ for GT and $119 \mathrm{bp} / 87 \mathrm{bp}$ for TT genotype respectively. Frequency of GG, GT and TT genotypes was $66.4 \%, 12.3 \%$ and $21.3 \%$ in PE with mild features, $65.2 \%, 12.5 \%$ and $22.3 \%$ in PE with severe features and $66 \%, 12 \%$ and $22 \%$ in total preeclamptic women as compared to controls (75\%, $14.5 \%$ and $10.5 \%)$ respectively. While frequency $\mathrm{G}$ and $\mathrm{T}$ alleles was $72.3 \%$ 
Table. 1 Clinical characteristics of controls and Preeclamptic groups

\begin{tabular}{|c|c|c|c|c|}
\hline Parameters & Controls $(n=300)$ & $\begin{array}{l}\text { PE with mild } \\
\text { features }(n=188)\end{array}$ & $\begin{array}{l}\text { PE with severe } \\
\text { features }(n=112)\end{array}$ & $\begin{array}{l}\text { Total } \\
\text { preeclamptic } \\
\text { women }(n=300)\end{array}$ \\
\hline Age (Years) & $27.017 \pm 0.32$ & $\begin{array}{l}28.14 \pm 0.42 \\
p \leq 0.001\end{array}$ & $\begin{array}{l}29.17 \pm 0.59 \\
p \leq 0.001\end{array}$ & $\begin{array}{l}28.52 \pm 0.34 \\
0.002\end{array}$ \\
\hline $\mathrm{BMI}\left(\mathrm{kg} / \mathrm{m}^{2}\right)$ & $27.67 \pm 0.28$ & $\begin{array}{l}28.72 \pm 0.47 \\
p \leq 0.001\end{array}$ & $\begin{array}{l}28.39 \pm 0.54 \\
p \leq 0.001\end{array}$ & $\begin{array}{l}28.59 \pm 0.360 \\
0.047\end{array}$ \\
\hline Gestational age (Weeks) & $36.32 \pm 0.36$ & $\begin{array}{l}33.14 \pm 0.48 \\
p \leq 0.001\end{array}$ & $\begin{array}{l}33.08 \pm 0.56 \\
p \leq 0.001\end{array}$ & $\begin{array}{l}33.12 \pm 0.15 \\
p \leq 0.001\end{array}$ \\
\hline Systolic Blood Pleasure $(\mathrm{mmHg})$ & $114.71 \pm 0.51$ & $\begin{array}{l}40.39 \pm 0.93 \\
p \leq 0.001\end{array}$ & $\begin{array}{l}174.94 \pm 2.02 \\
p \leq 0.001\end{array}$ & $\begin{array}{l}154.36 \pm 1.54 \\
p \leq 0.001\end{array}$ \\
\hline Diastolic Blood Pleasure (mmHg) & $73.88 \pm 0.45$ & $\begin{array}{l}93.10 \pm 0.86 \\
p \leq 0.001\end{array}$ & $\begin{array}{l}112.51 \pm 1.86 \\
p \leq 0.001\end{array}$ & $\begin{array}{l}100.95 \pm 1.12 \\
p \leq 0.001\end{array}$ \\
\hline Proteinuria & $0.08 \pm 0.03$ & $\begin{array}{l}2.1 \pm 0.04 \\
p \leq 0.001\end{array}$ & $\begin{array}{l}2.49 \pm 0.06 \\
p \leq 0.001\end{array}$ & $\begin{array}{l}2.29 \pm 0.05 \\
p \leq 0.001\end{array}$ \\
\hline Infant's weight (g)at birth & $3029.45 \pm 31.31$ & $\begin{array}{l}2600 \pm 130 \\
p \leq 0.001\end{array}$ & $\begin{array}{l}22,100 \pm 190 \\
p \leq 0.001\end{array}$ & $\begin{array}{l}2412.5 \pm 21.06 \\
p \leq 0.001\end{array}$ \\
\hline
\end{tabular}

All data are reported as mean \pm standard deviation with $\mathrm{p}=\mathrm{p}$ value, BMI, Body mass index

Table. 2 Pregnancy history of control group and preeclamptic groups

\begin{tabular}{|c|c|c|c|c|c|}
\hline Parameters & $\begin{array}{l}\text { Controls } \\
(n=300)\end{array}$ & $\begin{array}{l}\text { PE with mild features } \\
(n=188)\end{array}$ & $\begin{array}{l}\text { PE with severe } \\
\text { features } \\
(n=112)\end{array}$ & $\begin{array}{l}\text { Total preeclamptic } \\
\text { women } \\
(\mathrm{n}=300)\end{array}$ & $\begin{array}{l}\text { Total } \\
(n=600)\end{array}$ \\
\hline $\begin{array}{l}\text { Gravidity } \\
\text { Primary Gravida } \\
\text { Multiple Gravida }\end{array}$ & $\begin{array}{l}177(59) \\
123(41)\end{array}$ & $\begin{array}{l}145(77.13) \\
43(22.87) \\
p \leq 0.001\end{array}$ & $\begin{array}{l}80(71.43) \\
32(28.57) \\
p \leq 0.001\end{array}$ & $\begin{array}{l}225(75) \\
75(25) \\
p \leq 0.001\end{array}$ & $\begin{array}{l}402(67) \\
198(33)\end{array}$ \\
\hline $\begin{array}{l}\text { Preeclampsia in previous } \\
\text { pregnancy } \\
\text { Yes } \\
\text { No }\end{array}$ & $\begin{array}{c}15(5) \\
285(95)\end{array}$ & $\begin{array}{l}56(29.79) \\
132(70.21) \\
p \leq 0.001\end{array}$ & $\begin{array}{l}28(25) \\
84(75) \\
p \leq 0.001\end{array}$ & $\begin{array}{l}84(28) \\
216(72) \\
p \leq 0.001\end{array}$ & $\begin{array}{r}99(16.5) \\
501(83.5)\end{array}$ \\
\hline $\begin{array}{l}\text { Preeclampsia in Family } \\
\text { Yes } \\
\text { No }\end{array}$ & $\begin{array}{c}12(4) \\
288(96)\end{array}$ & $\begin{array}{l}43(22.87) \\
145(77.13) \\
p \leq 0.001\end{array}$ & $\begin{array}{l}35(31.25) \\
77(68.75) \\
p \leq 0.001\end{array}$ & $\begin{array}{l}78(26) \\
222(76) \\
p \leq 0.001\end{array}$ & $\begin{array}{r}90(15) \\
510(85)\end{array}$ \\
\hline
\end{tabular}

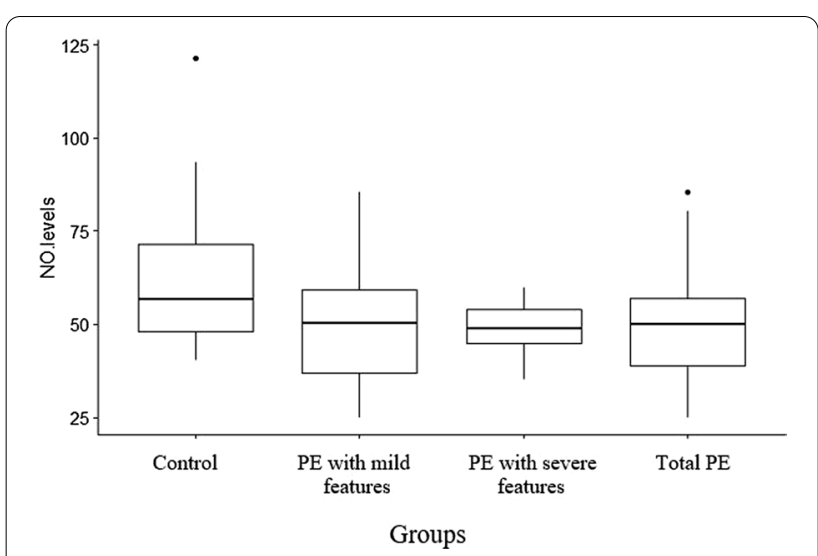

Fig. 1 Concentration of NO in controls and preeclamptic group and $27.7 \%$ in PE with mild features, $71.4 \%$ and $28.6 \%$ in PE with severe features while $72 \%$ and $28 \%$ in total preeclamptic individuals as compared to control group (82.25\% and $17.75 \%)$ respectively. Significant difference in frequency of c.894 $\mathrm{T}$ allele in PE with mild features $(\mathrm{p} \leq 0.001)$, severe $(\mathrm{p}=0.004)$ and total preeclamptic women $(\mathrm{p} \leq 0.001)$ was observed likewise c.894TT (p.298AspAsp) genotype showed higher frequency in PE with mild features preeclamptic individuals $(p=0.02)$, preeclamptic group with severe features $(p=0.03)$ and total preeclamptic women $(\mathrm{p}=0.008)$ as compared to control group.

As a result of electrophoresis eNOS 4b allele produced band of $420 \mathrm{bp}$ and $4 \mathrm{ba}$ allele produced bands of $4420 \mathrm{bp}$ 
Table. 3 Genotype distribution of eNOS 894 G/T, Intron 4b/4a, -786 T/C, -2051 G/A and -1861G/A haplotypes in controls and preeclamptic groups

\begin{tabular}{|c|c|c|c|c|c|}
\hline eNOS Variants & Genotype and Alleles & $\begin{array}{l}\text { Controls } \\
\text { (total } n=300) \\
n(\%)\end{array}$ & $\begin{array}{l}\text { PE with mild features } \\
\text { (total } n=188 \text { ) } \\
n(\%)\end{array}$ & $\begin{array}{l}\text { PE with severe features } \\
\text { (total } n=112 \text { ) } \\
n(\%)\end{array}$ & $\begin{array}{l}\text { Total preeclamptic } \\
\text { women } \\
\text { (total } \mathrm{n}=300) \\
\mathrm{n}(\%)\end{array}$ \\
\hline c.894G > T or p.(Glu298Asp) & GG & $225(75)$ & $125(66.4)$ & $73(65.2)$ & $198(66)$ \\
\hline \multirow[t]{8}{*}{ rs1799983 } & $\mathrm{TC}$ & $43(14.5)$ & $23(12.3)$ & $14(12.5)$ & $36(12)$ \\
\hline & TT & $32(10.5)$ & $40(21.3)$ & $25(22.3)$ & $66(22)^{*}$ \\
\hline & & & $\left(x^{2}=7.56, p=0.023\right)$ & $\left(X^{2}=6.79, P=0.033\right)$ & $\left(X^{2}=9.75, P=0.008\right)$ \\
\hline & Allele Frequency & & & & \\
\hline & G (Glu) & $493(82.25)$ & $272(72.3)$ & $160(71.4)$ & $432(72)$ \\
\hline & $\mathrm{T}($ Asp) & $107(17.75)$ & $104(27.7)$ & 64 (28.6) & $168(28)$ \\
\hline & & & $\left(x^{2}=22.78 p \leq 0.001\right)$ & $\left(x^{2}=7.91, p=0.004\right)$ & $\left(x^{2}=11.91, p \leq 0.001\right)$ \\
\hline & & & $\mathrm{OR}=2.27(1.61-3.2)$ & $\mathrm{OR}=1.862(1.20-2.88)$ & $\mathrm{OR}=1.80(1.28-2.52)$ \\
\hline Intron $4 a / 4 b$ & $\mathrm{Bb}$ & $272(90.5)$ & $159(84.6)$ & $99(88)$ & $258(86)$ \\
\hline \multirow[t]{8}{*}{ rs1722009 } & $\mathrm{Ba}$ & $28(9.5)$ & $29(15.4)$ & $13(12)$ & $42(14)$ \\
\hline & $\mathrm{Aa}$ & 0 & 0 & 0 & 0 \\
\hline & & & $\left(x^{2}=2.42, p=0.08\right)$ & $\left(x^{2}=0.37, p=0.34\right)$ & $\left(x^{2}=1.95, p=0.1\right)$ \\
\hline & Allele Frequency & & & & \\
\hline & $\mathrm{B}$ & $572(95.25)$ & $347(92.3)$ & $210(94)$ & $558(93)$ \\
\hline & A & $28(4.75)$ & $29(7.7)$ & $14(6)$ & $42(7)$ \\
\hline & & & $\left(x^{2}=2.51, p=0.08\right)$ & $\left(x^{2}=0.43, p=0.32\right)$ & $\left(x^{2}=2.07, p=0.09\right)$ \\
\hline & & & $\mathrm{OR}=1.69(0.87-3.26)$ & $\mathrm{OR}=1.31(0.58-2.97)$ & $\mathrm{OR}=1.54(0.85-2.82)$ \\
\hline g. $-786 \mathrm{~T}>\mathrm{C}$ & TT & $204(68)$ & $107(56.9)$ & $63(56)$ & $169(56.5)$ \\
\hline \multirow[t]{8}{*}{ rs2070744 } & $\mathrm{TC}$ & 79 (26.5) & $61(32.4)$ & $45(40)^{* *}$ & $104(34.5)^{* *}$ \\
\hline & CC & $17(5.5)$ & $20(10.7)^{*}$ & $4(4)$ & $27(9)^{*}$ \\
\hline & & & $\left(X^{2}=7.19, P=0.02\right)$ & $\left(X^{2}=7.24, P=0.02\right)$ & $\left(X^{2}=7.84, P=0.02\right)$ \\
\hline & Allele Frequency & & & & \\
\hline & $\mathrm{T}$ & $487(81.25)$ & $272(72.3)$ & $170(76)$ & $442(73.75)$ \\
\hline & C & $113(18.75)$ & $104(27.7)$ & $54(24)$ & $158(26.25)$ \\
\hline & & & $\left(x^{2}=6.98, p=0.006\right)$ & $\left(x^{2}=1.86, p=0.1\right)$ & $\left(x^{2}=6.45, p=0.007\right)$ \\
\hline & & & $\mathrm{OR}=1.65(1.13-2.40)$ & $\mathrm{OR}=1.36(0.87-2.14)$ & $\mathrm{OR}=1.54(1.10-2.15)$ \\
\hline g. $-2051 \mathrm{G}>\mathrm{A}$ & GG & $230(76.5)$ & $117(62.3)$ & $79(70.5)$ & $196(65.5)$ \\
\hline \multirow[t]{8}{*}{ rs553827594 } & GA & $51(17)$ & $36(19.1)$ & $10(9)$ & $47(15.5)$ \\
\hline & AA & $19(6.5)$ & $35(18.6)^{* *}$ & $23(20.5)^{* *}$ & $57(19)^{* * *}$ \\
\hline & & & $\left(X^{2}=12.19, P=0.002\right)$ & $\left(x^{2}=12.16, P=0.002\right)$ & $\left(X^{2}=7.45, P=0.02\right)$ \\
\hline & Allele Frequency & & & & \\
\hline & G & $511(85)$ & $270(72)$ & $168(75)$ & $439(73.25)$ \\
\hline & A & $89(15)$ & $106(28)$ & $56(25)$ & $161(26.75)$ \\
\hline & & & $\left(x^{2}=16.25, p<0.001\right)$ & $\left(x^{2}=7.01, p=0.008\right)$ & $\left(x^{2}=6.45, p=0.007\right)$ \\
\hline & & & $\mathrm{OR}=2.10(1.49-3.25)$ & $\mathrm{OR}=1.85(1.16-2.44)$ & $\mathrm{OR}=1.85(1.17-2.94)$ \\
\hline g. $-1861 G>A$ & GG & $212(71)$ & $123(65.4)$ & 78 (69.7) & $201(67)$ \\
\hline \multirow[t]{8}{*}{$\underline{\mathrm{rs} 1800779}$} & GA & $83(27.5)$ & $59(31.2)$ & $26(23.2)$ & $85(28.5)$ \\
\hline & $\mathrm{AA}$ & $5(1.5)$ & $6(3.2)$ & $8(7.1)^{*}$ & $14(4.5)$ \\
\hline & & & $\left(X^{2}=1.72, P=0.42\right)$ & $\left(x^{2}=5.27, P=0.07\right)$ & $\left(x^{2}=3.26, P=0.19\right)$ \\
\hline & Allele Frequency & & & & \\
\hline & G & $507(84.75)$ & $305(81.2)$ & $182(81.25)$ & $487(81.25)$ \\
\hline & A & $93(15.25)$ & 71 (18.8) & $42(18.75)$ & $113(18.75)$ \\
\hline & & & $\left(x^{2}=1.39, p=0.23\right)$ & $\left(x^{2}=0.93, p=0.33\right)$ & $\left(x^{2}=1.73, p=0.18\right)$ \\
\hline & & & $\mathrm{OR}=1.28(0.84-1.95)$ & $\mathrm{OR}=1.27(0.77-2.08)$ & $\mathrm{OR}=1.28(0.88-1.85)$ \\
\hline
\end{tabular}


Table. 3 (continued)

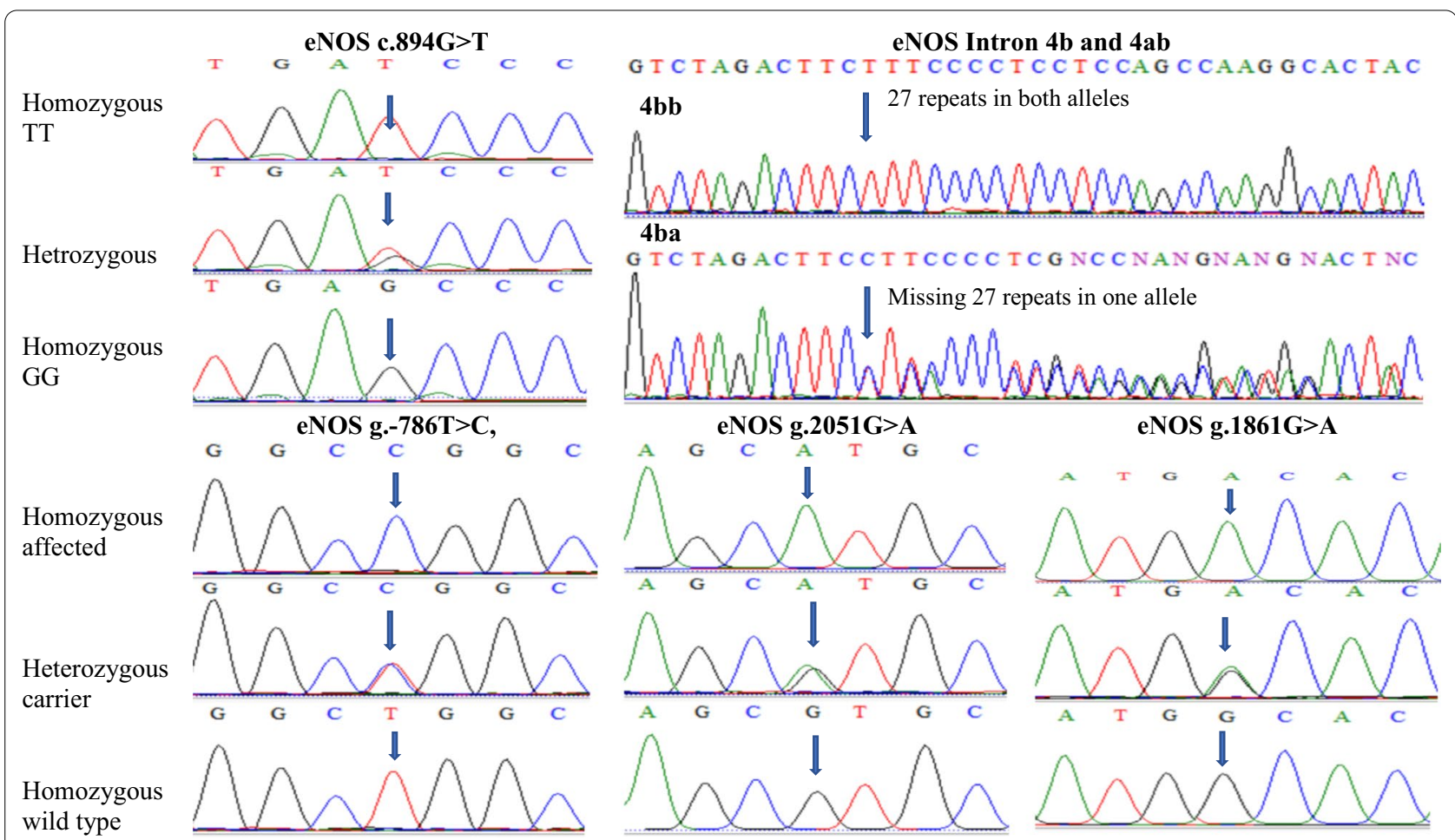

Fig. 2 Sequence analysis of eNOS gene variants

and $393 \mathrm{bp}$. Intron 4bb and 4ba genotypes were found in $84.6 \%$ and $15.4 \%$ individuals of PE with mild features, $88 \%$ and $12 \%$ subjects of severe features however $86 \%$ and $14 \%$ women of total preeclamptic group as compared to control subjects (90.5\% and 9.55). aa genotype was found in none of the patients or control subjects. Frequency of $b$ and a allele was $92.3 \%$ and $7.7 \%$ in PE with mild features, $94 \%$ and $6 \%$ in PE with severe features group while $93 \%$ and $7 \%$ in total preeclamptic individuals as compared to control group (95.25\% and $4.75 \%$ ). Frequency of intron $4 \mathrm{~b} / 4 \mathrm{~b}$ and intron $4 \mathrm{~b} / 4 \mathrm{a}$ showed no significant difference in all three groups $(\mathrm{p}=0.08, \mathrm{p}=0.32$ and $\mathrm{p}=0.09)$ as compared to normotensive pregnant females.

Electrophoresis for g.-786 $\mathrm{T}>\mathrm{C}$ variant showed first band of 387 bp which was control band in both PCR reaction ( $\mathrm{T}$ and $\mathrm{C}$ ) and second band of $250 \mathrm{bp}$, corresponds to $\mathrm{T}$ and $\mathrm{C}$ allele indicating homozygous genotype (TT and $\mathrm{CC}$ ), and heterozygous genotype (TC) in case of both bands in both reactions. Genotypic distribution of g.-786TT, TC and CC was 56.9\%, $32.4 \%$ and $10.7 \%$ in PE with mild features, $56 \%, 40 \%$ and $4 \%$ in PE with severe features however $56.5 \%, 34.5 \%$ and $9 \%$ in total preeclamptic women when compared to control group (68\%,
$26.5 \%$ and $5.5 \%$ ). The frequency of g.-786C allele was significantly different in PE with mild features $(p=0.006)$ and total preeclamptic group $(\mathrm{p}=0.007)$ as compared to healthy controls. Likewise, g.-786TC genotype determined significant difference in PE with severe features $(\mathrm{p}<0.01)$ and total preeclamptic group $(\mathrm{p}<0.01)$ when compared to normotensive control group. G.-786CC genotype showed significant difference in PE with mild features $(\mathrm{p}<0.05)$ and total preeclamptic group $(\mathrm{p}<0.05)$ as compared to control group.

Other variants g.-2051G > A (rs553827594, in novel homozygous AA genotype) and g.-1861G > A (rs1800779) were also found in preeclamptic women in homozygous GG, heterozygous GA and homozygous AA genotypes. g.-2051G $>$ A showed significant association with all PE $(p=0.02)$ groups as compared to control group, while the non-significant association of g.-1861G $>$ A was found between groups as shown in Table 2 and Fig. 2. Which may have a possible association with preeclampsia.

\section{Structural analysis}

Ramachandran plot for $e N O S^{\text {Glu298Asp }}$ structure indicated overall $>93 \%$ of residues in the allowed region (Fig. 3). 

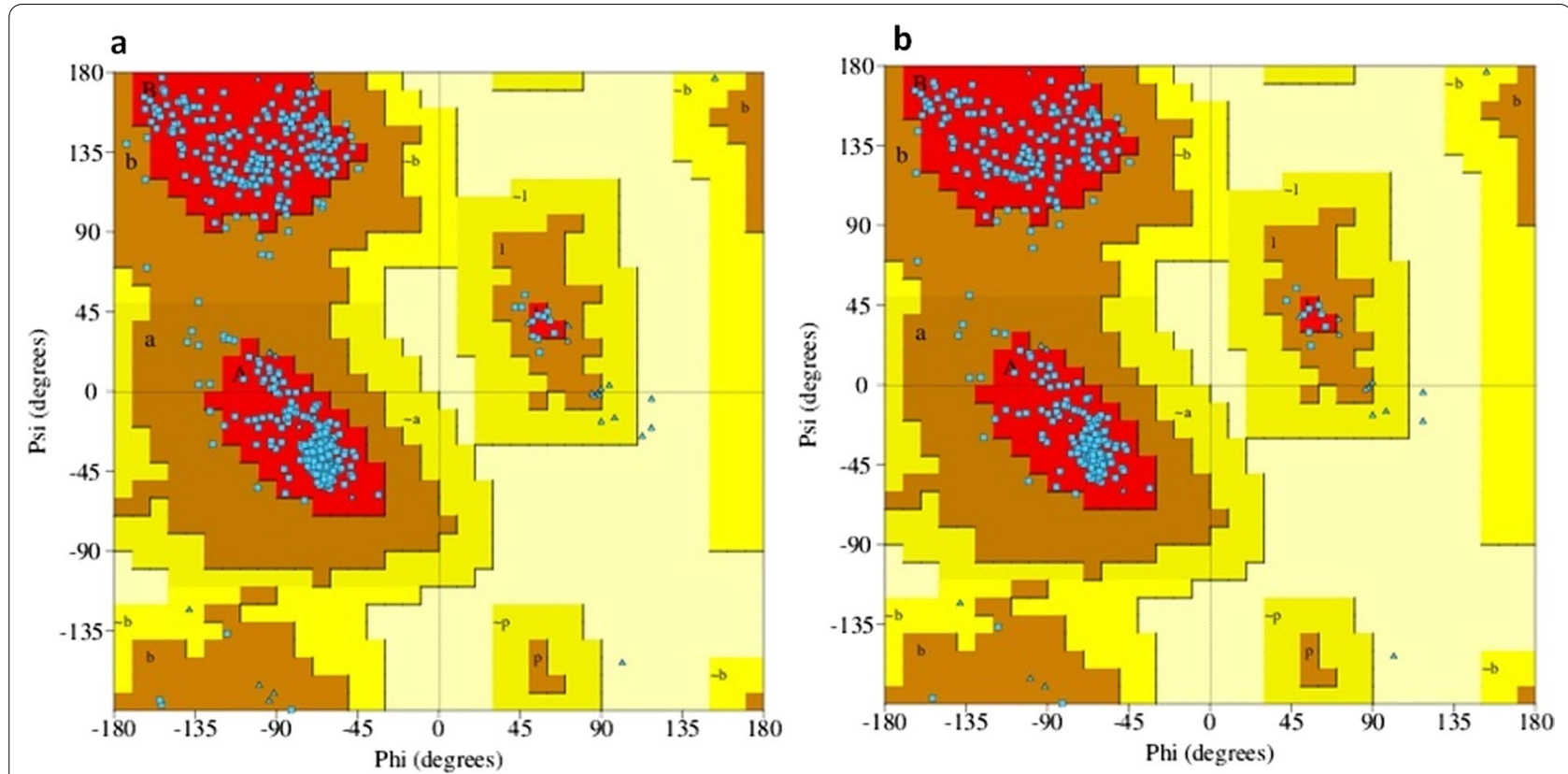

Fig. 3 Ramachandran plot. a eNOS ${ }^{W T}$, b eNOS Glu298Asp

This shows that structure is of good quality and can be used for the structure-activity study. Structural analysis revealed the fact that this substitution changed the overall topology of the eNOS protein. Upon mutation stability of the protein changes with destabilizing energy of $\Delta \Delta \mathrm{G}:-0.071 \mathrm{kcal} / \mathrm{mol}$. The flexibility of the protein was also changed with vibrational entropy change of $\Delta \Delta \mathrm{S}_{\mathrm{Vib}}$ ENCoM: $-0.396 \mathrm{kcal}^{\mathrm{mol}}{ }^{-1} \cdot \mathrm{K}^{-1}$. Several atomic fluctuations were observed throughout the eNOS protein (Fig. 4).

\section{Molecular dynamics simulation analysis} The $e N O S^{\mathrm{WT}}$ and $e N O S^{\mathrm{Glu} 298 \mathrm{Asp}}$ structures were further analyzed by molecular dynamics (MD) simulation assay to study the time-dependent behavior and overall stability of the system. secondary structural elements stability and conformational deviations of all atom trajectories were used to plot the root mean square fluctuation (RMSF) and root mean square deviation (RMSD). In $e N O S^{\mathrm{WT}}$ the high fluctuation was observed between 150300 residues and the systems remain stable throughout the protein length. The RMSF analysis of eNOS ${ }^{\text {Glu298Asp }}$ indicated fluctuation in the loops near mutant residue at 298 position. The high RMSF fluctuation rate of the $e N O S^{\text {Glu298Asp }}$ per residue indicated high fluctuation rate in the C-terminus regions of the protein. To our surprise region encompassing the substitution Glue298Asp indicated more fluctuation upto $5 \mathrm{~A}^{\circ}$. This high fluctuation indicated that this substitution has negative impact on protein stability (Fig. 5).

\section{Transcription factor binding Site prediction and DNA modeling}

ConTraV3 (http://bioit2.irc.ugent.be/contra/v3) and JASPER database revealed Signal transducer and activator of transcription 3 (STAT 3) and Signal transducer and activator of transcription 6 (STAT6) transcription binding site in the promoter region of eNOS gene (Fig. 6). STAT3 is a transcription factor involved in cell proliferation, inflammation, differentiation, and survival (Qi QR and Yang ZM., 2014). STAT6/IL-4 pathway is important for normal pregnancy (KR bound., 2017). Variants in the promoter region $(-786 \mathrm{~T}>\mathrm{C}$ and $-2015 \mathrm{G}>\mathrm{A})$ abolished the binding site for Stat3 and Stat 6 respectively. Normal and mutant DNA molecules were modeled for the promoter region of $e N O S$ gene (Fig. 7).

\section{Docking analysis of eNOS promoter with STAT3 and STAT6}

STAT3 and STAT6 protein's surface were assessed through molecular docking to investigate its potential for eNOS promoter region. Rigid body docking of eNOS DNA with STAT3 and STAT6 revealed important structural insight into the binding of DNA major and minor grooves. Mixture of major and minor grooves are involved in binding with respective transcription factor. Computational docking gave a perfect fit of binding of normal DNA with STAT3 and STAT6 protein while mutant promoter DNA moved away from the binding interface of both (STA3 and STAT6) transcription factor (Fig. 8). 


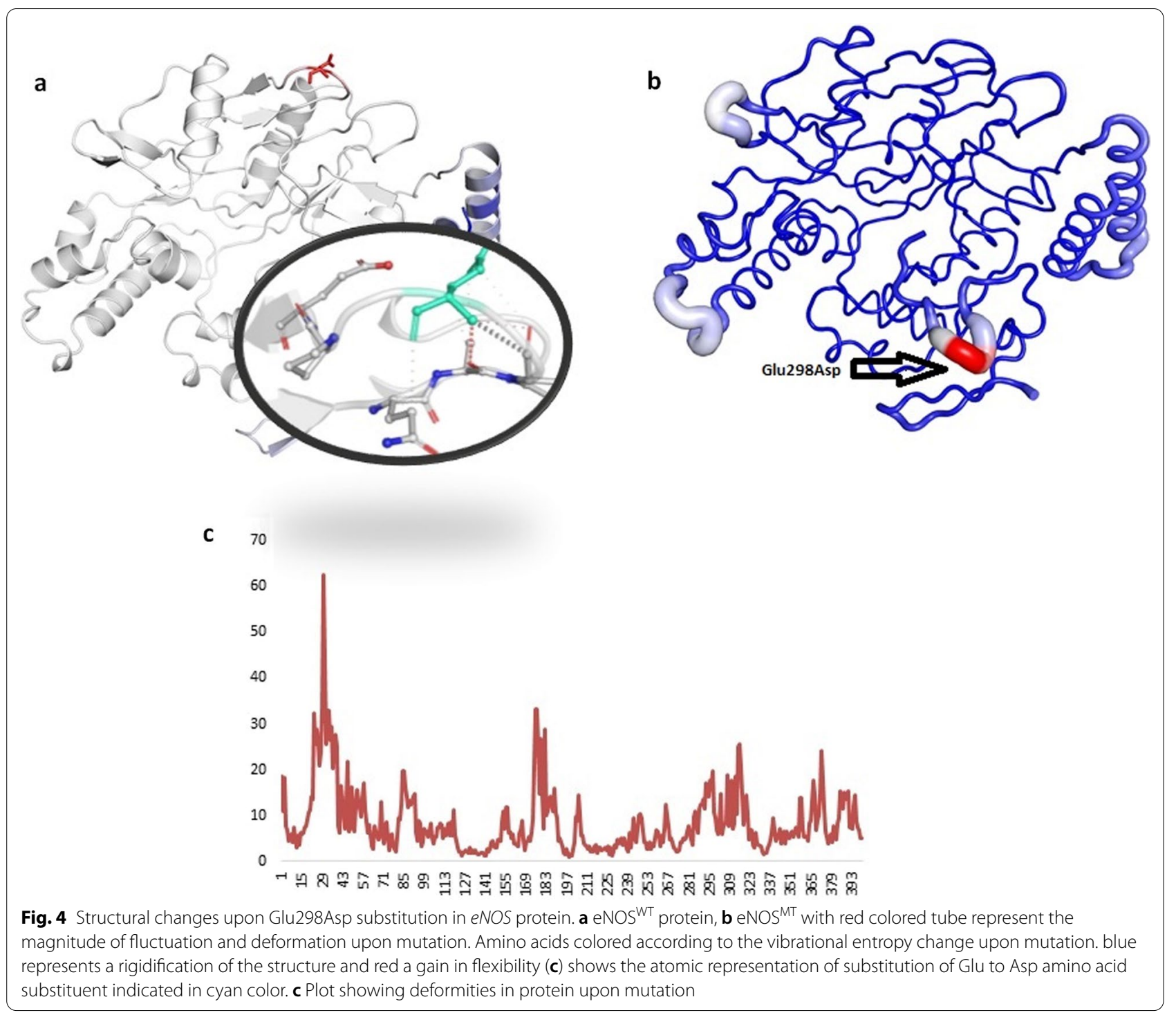

\section{Discussion}

$\mathrm{PE}$ is an important maternal health problem, especially in developing countries like Pakistan. Maternal Mortality is extremely high in Pakistan where 1 in 89 women dies of maternal causes with PE and eclampsia as one of the major causes [8]. Identification of various factors and candidate genes could help in understanding this complication and provide clues for its management and treatment. Genome wide association studies have been done on various population presenting the involvement of different genes and their variants [3638]. In addition endothelial dysfunction, role of eNOS gene and reduced NO production has been associated with PE $[11,16,39]$. This study was the first to assess the potential role of NO levels and eNOS gene variants in preeclamptic women as compared to healthy normotensive pregnant women in Pakistan.

According to current study, maternal age body mass index (BMI), systolic and diastolic blood pressure, Gestational age between control and preeclamptic groups showed significant role in PE. Similar results were reported previously studies presenting that women with increased age and BMI had twice the risk of developing $\mathrm{PE}$ and increases up to $30 \%$ in every additional year of age past [40-42]. History of PE in previous pregnancy and family history of preeclampsia also predicts the association with the onset of PE. Family history of PE is associated with a fourfold increased risk of PE in women, underlying mechanism may involve the predisposition of various genetic factor involved in the pathophysiology 


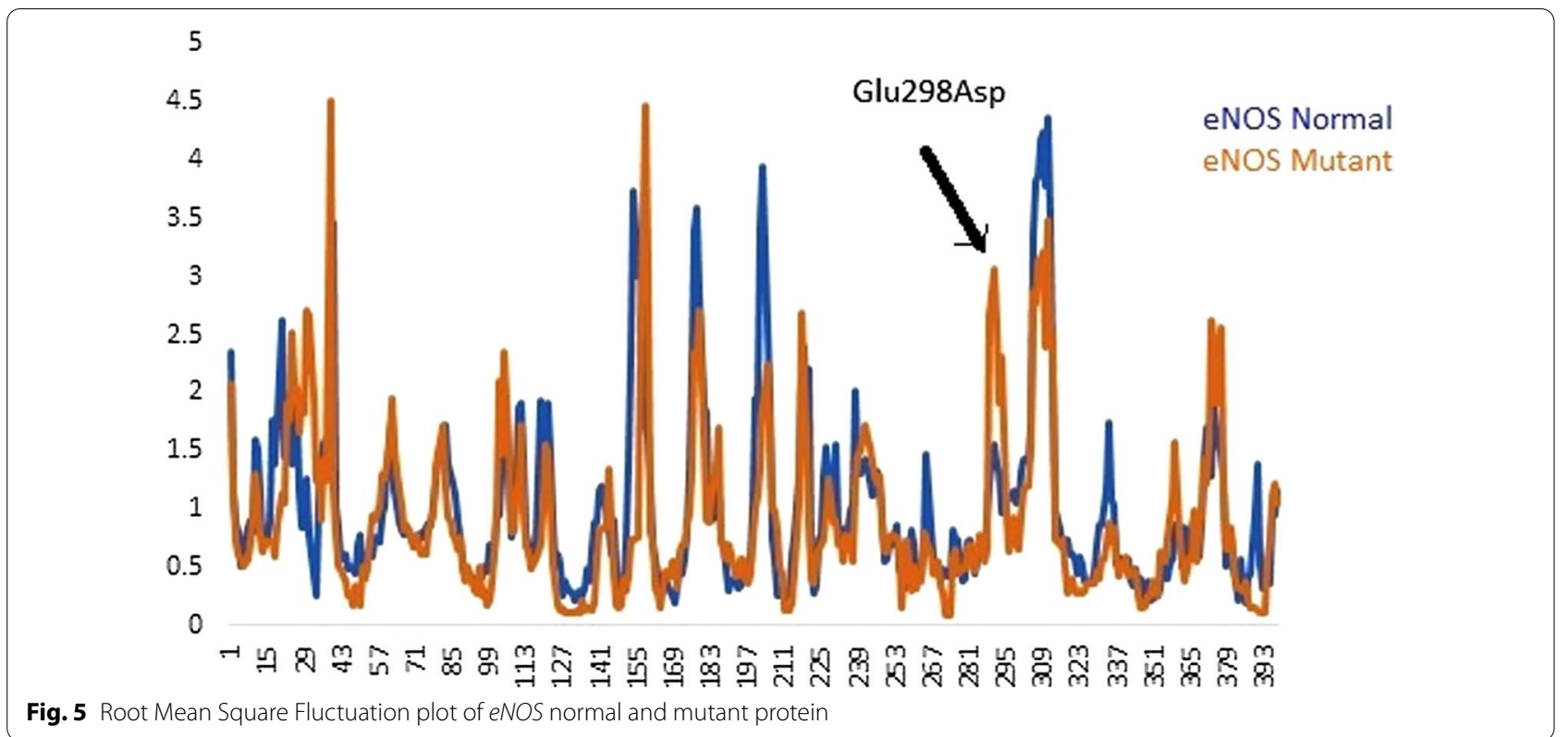

Fig. 5 Root Mean Square Fluctuation plot of eNOS normal and mutant protein

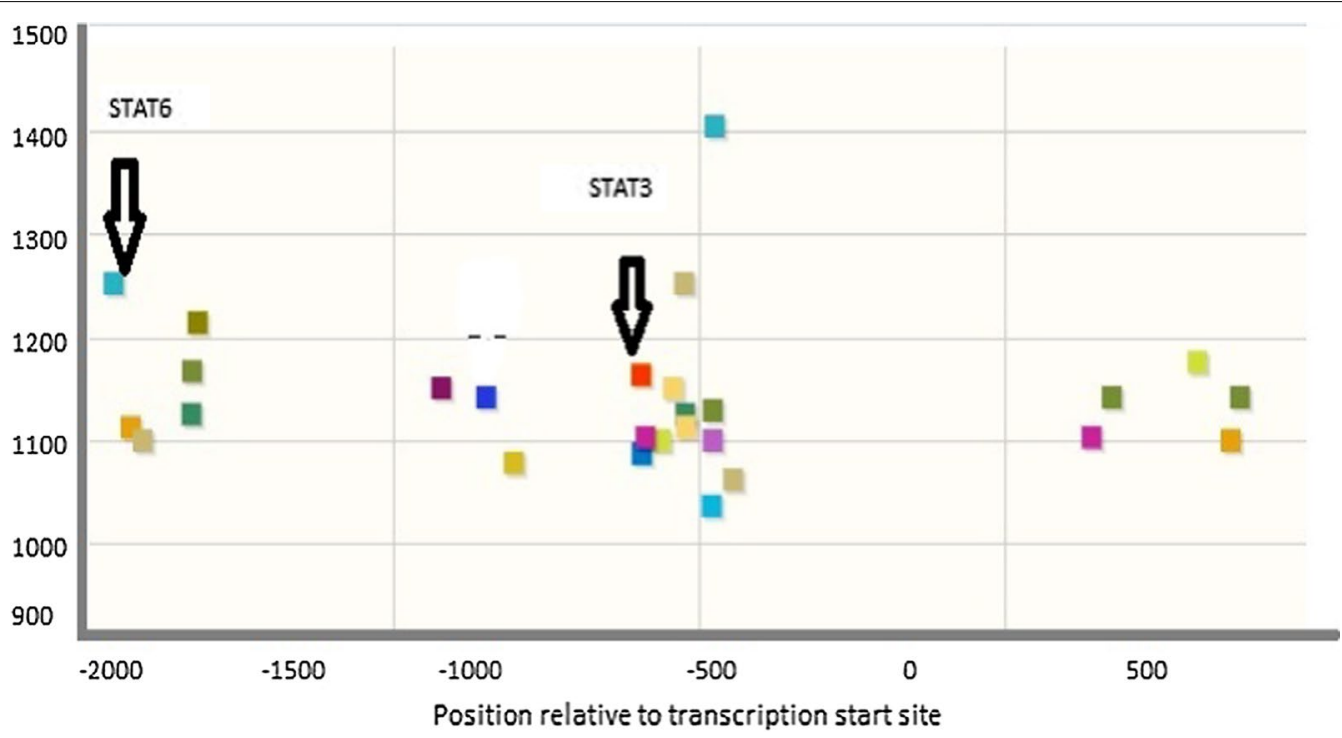

Fig. 6 Scatter plot of TF binding sites on eNOS promoter

of PE [41, 43]. Results of the current study revealed that levels of NO were significantly lower in preeclamptic group as compared to controls in accordance with previous findings [10, 44-46]. Due to its short half-life, the direct measurement of $\mathrm{NO}$ is extremely challenging in a complex biological environment. As NO is rapidly metabolized to nitrite and nitrate in the presence of oxygen, the determination of both nitrite and nitrate (termed NOx) is commonly used to estimate total NO production. A major general disadvantage of nitrite/ nitrate determination to estimate tissue NO level is that dietary intake of nitrite (e.g. cured meat) and nitrate (e.g. vegetables) are rather significant, which markedly influences plasma NOx level [47]. The Griess reaction was used for the determination of $\mathrm{NO}$ in current study it is also called diazotization assay which is based on the conversion of nitrite to a purple-coloured azo-dye that can be spectrophotometrically assayed at a wavelength of $\sim 540 \mathrm{~nm}$. Advantages of this method include a strong literature background, numerous commercially available reagent kits and wide availability of infrastructure [48]. It was evident previously that impair NO levels attenuated 


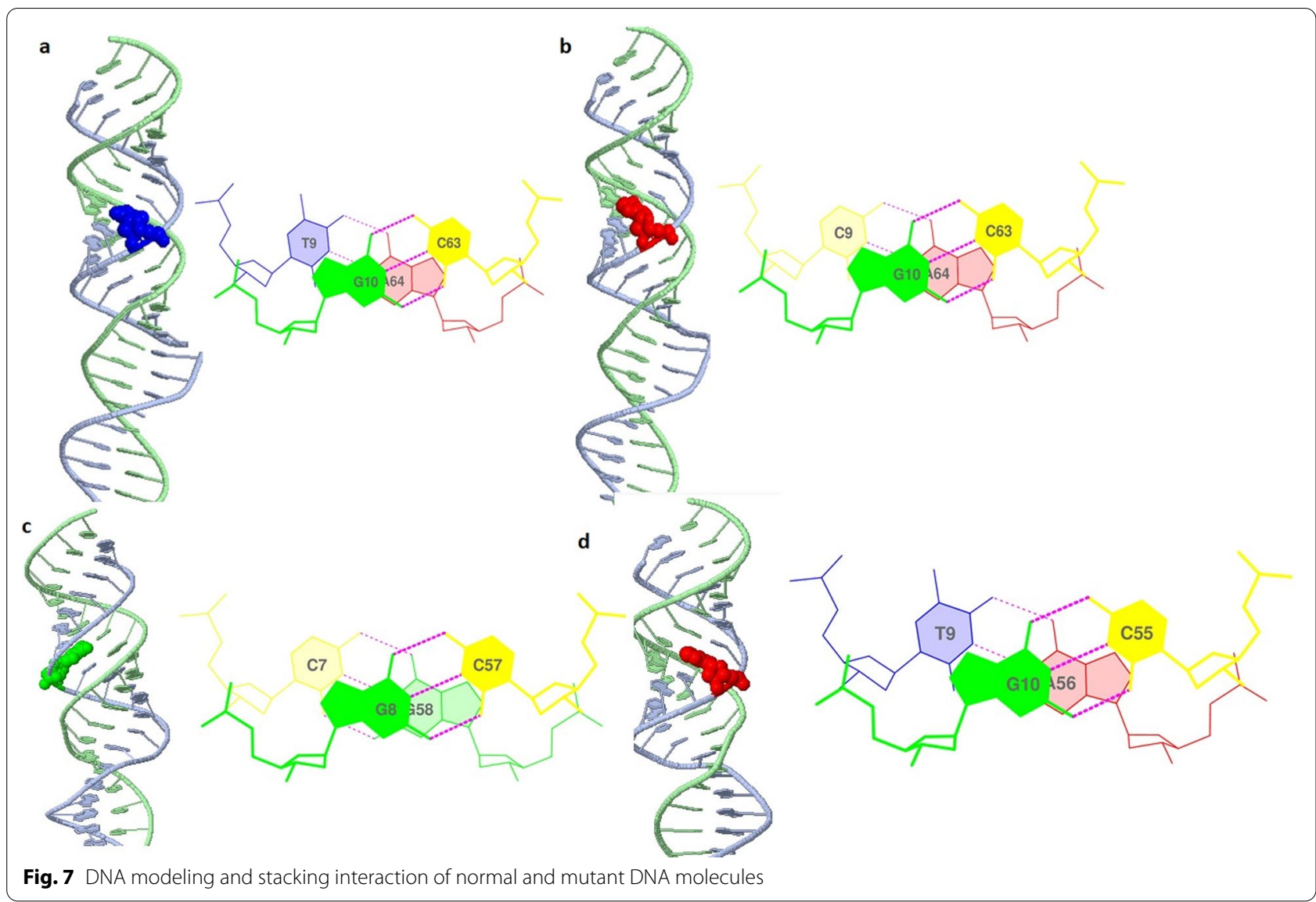

the acetylcholine-induced relaxation in arteries of preeclamptic women placentas causing vasoconstriction leading to increased mother's blood pressure [49, 50]. Therefore, circulating NO is likely to be important for fetoplacental hemodynamics ensuring adequate placental blood flow and fetal oxygenation [17].

In present study common variants of eNOS gene including c.894G $>\mathrm{T}$ (p.(Glu298Asp)), intron 4b/4a and g.-786 $\mathrm{T}>\mathrm{C}$ were analyzed by genotyping and confirmed through sequencing. The significant association was found for c.894G > T (p.(Glu298Asp)), variant. It was demonstrated that eNOS c.894 T (p.298Asp) was significantly associated with PE. Our findings are in correspondence with previous studies [1, 15, 18, 20]. A likely mechanism by which c.894 $\mathrm{T}$ (p.298Asp) might reduce the bioavailability of $\mathrm{NO}$ has been reported. Various studies have shown that p.298 Asp is subjected to selective proteolytic cleavage in vascular tissues and endothelial cells resulting in reduced vascular NO generation in subjects homozygous for this variant $[20,51,52]$. In addition, p.(Glu298Asp) modulates eNOS activity by interacting with other proteins involved in the degradation of its product, and hence its intracellular distribution [52]. Thus, women with homozygous Asp298 allele are more susceptible to endothelial dysfunction which might increase the risk of PE, observed in the present study as well.

Regarding the eNOS intron $4 \mathrm{~b} / 4 \mathrm{a}$ variant, non-significant association has been observed in present study as demonstrated by previously in different populationbased case control studies [11, 16, 21, 53-55]. Possible reason might be its intronic region which is unlikely to be functional in its own right [15].

The association of g.-786 $\mathrm{T}>\mathrm{C}$ variant with $\mathrm{PE}$ seen here agreed with the results established earlier for different regions of the world [21, 39, 53, 56, 57]. The present study demonstrated that g.-786C allele was prevailing in PE patients as compared to control. The g. $-798 \mathrm{C}$ allele in the $e N O S$ promoter region has been associated with reduced mRNA expression and lower serum nitrite/nitrate levels Causing unavailability of NO [58]. It was also suggested that $50 \%$ of $e N O S$ activity can be reduced if its transcription is repressed by targeting g.-786C allele through single-stranded DNA binding transcription factor replication protein, A1 which results in lower NO production $[59,60]$. Interestingly, the eNOS haplotype ('C Glu a') was also found in association with responsiveness to antihypertensive 


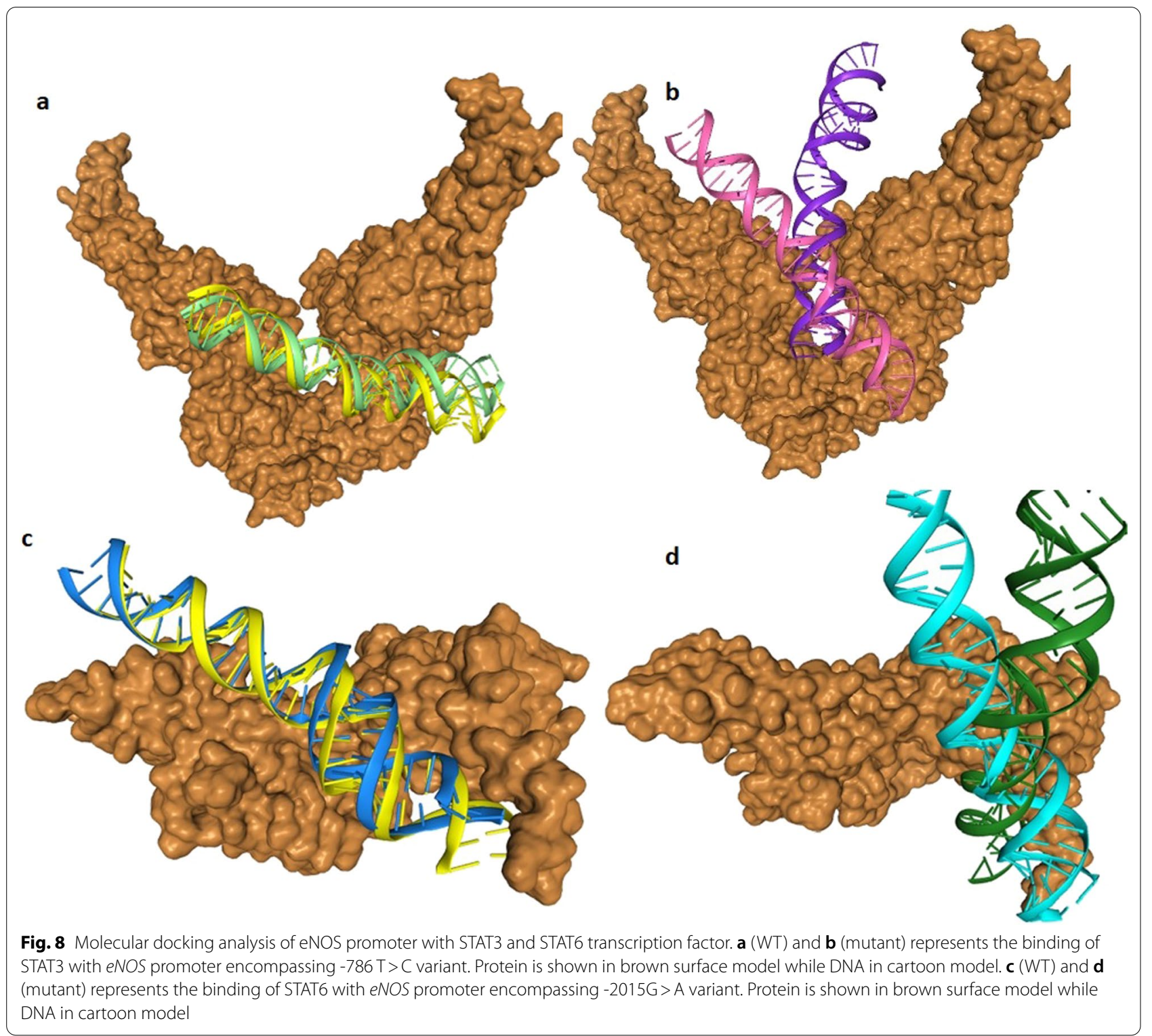

therapy in PE patients. It is possible that this particular eNOS haplotype leads to a lower NO availability in PE patients, which is improved by antihypertensive drugs. [61].

Sequencing revealed the association of another variant with the disease phenotype that is g.2051G > A which was present in the promoter region of the eNOS gene. Genetic analysis showed that previously this variant was associated with the disease phenotype in heterozygous form but in accordance with resent study it was also determined to be homozygous for g.2051AA. This variant might affect the transcription of the eNOS gene through unknown mechanism and results in reduced NO levels leading to endothelial dysfunction.
Through our in silico deep structural analysis, we elucidated the structural and functional behavior of eNOS protein upon Glu298Asp substitution. The reported substitution resulted in the loss of flexibility and deformities were reported that alter the conformation and configuration of the protein and ultimately decrease protein stability. Molecular dynamic simulation analysis revealed that due to Glu298Asp substitution there was alteration in protein structural behavior and fluctuations were observed in the loop region encompassing the mutation and this alteration might play a role in causing preeclampsia. Detailed illustration of a structural and functional behavior of eNOS uncovers underlying molecular mechanism and 
may aid in the development of a potent therapeutic drug. Secondly the mutations reported in the promoter region of the eNOS gene changed the binding of transcription factor STAT3 and STAT6 to the 5' site of the eNOS gene. These reported variants might change the regulation of eNOS gene and responsible reduced NO level and leading to endothelial dysfunction.

\section{Conclusion}

The present study revealed substantial association of c.894G > T (p.(Glu298Asp)) and g. -786 T $>C$ variants while no association of intron $4 \mathrm{~b} / 4 \mathrm{a}$ variant in Pakistani population. Data from the current study suggest that there might be other risk variants of the eNOS gene (g.2051G > A and g.1861G > A) and lower levels of serum $\mathrm{NO}$ that confers in an increased risk of PE. The detailed computational investigation further confirmed the deformities and changes in protein flexibility upon Glu298Asp. These structural alterations might be associated with PE. Variants in the promoter region of the eNOS gene further validate the change in gene regulation for the onset of disease. Identification of key structural and functional features in eNOS protein and gene regulatory region might be used for designing specific drugs for therapeutic purpose.

\section{Future perspective}

Intense care units for PE should in every city in Pakistan for prompt diagnosis of $\mathrm{PE}$ in community settings are necessary to ensure maternal and fetal well-being. Genetic testing and NO concentration in maternal serum could be used as a biomarker to predict PE for practicing clinicians, which could also help in interfering PE development in the early period in preeclamptic Pakistani women. Limitations of the current study include small sample size, no follow up and limited resources so, large study or meta-analysis and follow up studies are needed to define the contribution of $e N O S$ variants and altered NO production in PE pathogenesis and associated features. Further collaborative research in PE may help in elucidating the contributory role of $e N O S$ variants by performing genetic association studies and genome-wide association studies with adequate credibility. Understanding of etiology of PE and the role played by the differences in the environmental factors in developed and developing countries should be a research priority to prevent maternal and neonatal morbidity and mortality.

\section{Abbreviations}

PE: Preeclampsia; eNOS: Endothelial nitric oxide synthase; NO: Nitric oxide; SEM: Standard error of mean.

\section{Supplementary Information}

The online version contains supplementary material available at https://doi. org/10.1186/s12978-021-01213-9.

Additional file 1: Figure S1. Pie chart showing percentage of subjects included in the study from different areas of Pakistan.

\section{Acknowledgements}

The authors would like to extend their sincere appreciation to the Deanship of Scientific Research, King Saud University, KSA for funding through Vice Deanship of Scientific research chairs.

\section{Authors' contributions}

GA, NB, SJ, SR, TA, MA, MHA AAK made significant contributions to conception, design, experimentation, acquisition and interpretation of data and writing of manuscript. AU, IA, RF, TA, SR, DD, MA, MHA, AAK and AA made substantial contribution in interpretation of data and revising the manuscript for intellectual content. All authors read and approved the final manuscript.

Funding

The project was partially funded by the Higher Education Commission (HEC) of Pakistan by awarding an indigenous scholarship to the first author.

Availability of data and materials

All the data are contained in the manuscript.

\section{Declaration}

\section{Ethics approval and Consent to participate}

This study makes use of Humans, and the experimental protocol for the use of humans was approved (BAS\#0205) by the ethical board of Quaid-i-Azam University, Islamabad Pakistan. This study makes use of humans, and the experimental protocol for the use of humans was approved.

\section{Consent to publication}

Not applicable.

\section{Competing interests}

The authors declare that they have no competing interests.

\section{Author details}

${ }^{1}$ Department of Animal Sciences, Faculty of Biological Sciences, Quaid-I-Azam University, Islamabad 45320, Pakistan. ${ }^{2}$ Department of Bioinformatics, Shaheed Benazir Bhutto Women University, Peshawar, Pakistan. ${ }^{3}$ College of Applied Medical Sciences, Community Health Sciences, King Saud University, Riyadh, Kingdom of Saudi Arabia. ${ }^{4}$ Department of Biochemistry, Faculty of Biological Sciences, Quaid-I-Azam University, Islamabad 45320, Pakistan. ${ }^{5}$ Department of Microbiology, Faculty of Biological Sciences, Quaid-I-Azam University, Islamabad 45320, Pakistan. ${ }^{6}$ Dental Biomaterials Research Chair, Dental Health Department, College of Applied Medical Sciences, King Saud University, Riyadh, Kingdom of Saudi Arabia.

Received: 22 October 2020 Accepted: 21 July 2021 Published online: 28 July 2021

\section{References}

1. Chen Y, Wang D, Zhou M, Chen X, Chen J. Polymorphisms of the endothelial nitric oxide synthase gene in preeclampsia in a Han Chinese population. Gynecol Obstet Invest. 2014;77(3):150-5.

2. Du L, He F, Kuang L, Tang W, Li Y, Chen D. eNOS/iNOS and endoplasmic reticulum stress-induced apoptosis in the placentas of patients with preeclampsia. J Hum Hypertens. 2017;31(1):49.

3. Brown MA, Magee LA, Kenny LC, Karumanchi SA, McCarthy FP, Saito S, Hall DR, Warren CE, Adoyi G, Ishaku S. Hypertensive disorders of pregnancy: ISSHP classification, diagnosis, and management recommendations for international practice. Hypertension. 2018;72(1):24-43. 
4. Dai B, Liu T, Zhang B, Zhang X, Wang Z. The polymorphism for endothelial nitric oxide synthase gene, the level of nitric oxide and the risk for preeclampsia: a meta-analysis. Gene. 2013;519(1):187-93.

5. Lisowska M, Pietrucha T, Sakowicz A. Preeclampsia and related cardiovascular risk: common genetic background. Curr Hypertens Rep. 2018;20(8):71

6. Myatt L, Redman CW, Staff AC, Hansson S, Wilson ML, Laivuori H, Poston L, Roberts JM. Strategy for standardization of preeclampsia research study design. Hypertension. 2014;63(6):1293-301.

7. Goulopoulou S, Davidge ST. Molecular mechanisms of maternal vascular dysfunction in preeclampsia. Trends Mol Med. 2015;21(2):88-97.

8. Shamsi U, Hatcher J, Shamsi A, Zuberi N, Qadri Z, Saleem S. A multicentre matched case control study of risk factors for preeclampsia in healthy women in Pakistan. BMC Womens Health. 2010;10(1):14.

9. Naseeb S, Bano K, Korejo R. Maternal and perinatal outcome of preeclampsia and eclampsia treated with magnesium sulphate. J Surg Pakistan. 2015;20:4.

10. Singh A, Sharma D, Raghunandan C, Bhattacharjee J. Role of inflammatory cytokines and eNOS gene polymorphism in pathophysiology of pre-eclampsia. Am J Reprod Immunol. 2010;63(3):244-51.

11. Gannoun MBA, Zitouni H, Raguema N, Maleh W, Gris J-C, Almawi W, Mahjoub T. Association of common eNOS/NOS3 polymorphisms with preeclampsia in Tunisian Arabs. Gene. 2015;569(2):303-7.

12. George EM, Granger JP. Recent insights into the pathophysiology of preeclampsia. Expert Rev Obstetr Gynecol. 2010;5(5):557-66.

13. Devendran A, Nampoothiri S, Shewade DG, Chatterjee S, Jayaraman $B$, Chandrasekharan A. Allele, genotype and haplotype structures of functional polymorphic variants in Endothelial nitric oxide synthase (eNOS), Angiotensinogen (ACE) and Aldosterone synthase (CYP11B2) genes in healthy pregnant women of Indian ethnicity. J Reprod Infert. 2015;16(4):180.

14. Palmer R, Ashton D, Moncada S. Vascular endothelial cells synthesize nitric oxide from L-arginine. Nature. 1988;333(6174):664-6.

15. Serrano NC, Casas JP, Díaz LA, Páez C, Mesa CM, Cifuentes R, Monterrosa A, Bautista A, Hawe E, Hingorani AD. Endothelial NO synthase genotype and risk of preeclampsia: a multicenter case-control study. Hypertension. 2004:44(5):702-7.

16. Rahimi Z, Aghaei A, Rahimi Z, Vaisi-Raygani A. Endothelial nitric oxide synthase (eNOS) 4a/b and G894T polymorphisms and susceptibility to preeclampsia. J Reprod Infert. 2013:14(4):184.

17. Turan F, Ilhan N, Kaman D, Ateş K, Kafkaslı A. Glu298Asp polymorphism of the endothelial nitric oxide synthase gene and plasma concentrations of asymmetric dimethylarginine in Turkish pre-eclamptic women without fetal growth retardation. J Obstetr Gynaecol Res. 2010;36(3):495-501.

18. Maria Procopciuc L, Caracostea G, Maria Hazi G, Nemeti G, Zaharie G, Stamatian F. Maternal/fetal eNOS-Glu298Asp genotypes and their influence on the severity, prognosis, and lipid profile of preeclampsia. J Matern Fetal Neonatal Med. 2018;31(13):1681-8.

19. Hocher B, Chen Y, Hügle S, Repey J, Krause K, Slowinski T, Godes M, Schaeffeler E, Guthmann F, Wauer R. Impact of maternal endothelial nitric oxide synthase gene polymorphisms on blood pressure, protein excretion and fetal outcome in pregnancy. J Hum Hypertens. 2008;22(9):641.

20. Alpoim PN, Gomes KB, de Pinheiro M, Godoi LC, Jardim LL, Muniz LG, Sandrim VC, Fernandes AP, Dusse LMS. Polymorphisms in endothelial nitric oxide synthase gene in early and late severe preeclampsia. Nitric Oxide. 2014;42:19-23.

21. Zdoukopoulos N, Doxani C, Messinis IE, Stefanidis I, Zintzaras E. Polymorphisms of the endothelial nitric oxide synthase (NOS3) gene in preeclampsia: a candidate-gene association study. BMC Pregn Childbirth. 2011;11(1):89

22. Qi HP, Fraser WD, Luo ZC, Julien P, Audibert F, Wei SQ. Endothelial nitric oxide synthase gene polymorphisms and risk of preeclampsia. Am J Perinatol. 2013;30(10):795-804.

23. Practice ACOO. ACOG practice bulletin. Diagnosis and management of preeclampsia and eclampsia. Number 33, January 2002 American College of Obstetricians and Gynecologists. Int J Gynaecol Obstetr 2002, 77(1):67.

24. Kidron D, Vainer I, Fisher Y, Sharony R. Automated image analysis of placental villi and syncytial knots in histological sections. Placenta. 2017:53:113-8.
25. Laskowski RA, Rullmann JAC, MacArthur MW, Kaptein R, Thornton JM. AQUA and PROCHECK-NMR: programs for checking the quality of protein structures solved by NMR. J Biomol NMR. 1996;8(4):477-86.

26. Pettersen EF, Goddard TD, Huang CC, Couch GS, Greenblatt DM, Meng EC, Ferrin TE. UCSF Chimera - a visualization system for exploratory research and analysis. J Comput Chem. 2004;25(13):1605-12.

27. Duan Y, Wu C, Chowdhury S, Lee MC, Xiong G, Zhang W, Yang R, Cieplak $P$, Luo R, Lee T. A point-charge force field for molecular mechanics simulations of proteins based on condensed-phase quantum mechanical calculations. J Comput Chem. 2003;24(16):1999-2012.

28. Zlenko D. Diffusion factor calculation for TIP4P model of water. Biofizika. 2012:57(2):197-204

29. Humphrey W, Dalke A, Schulten K. VMD: visual molecular dynamics. J Mol Graphics. 1996;14(1):33-8.

30. Pant P, Afshan Shaikh S, Jayaram B. Design and characterization of symmetric nucleic acids via molecular dynamics simulations. Biopolymers. 2017;107(4):e23002.

31. Pant P, Pathak A, Jayaram B. Symmetrization of the backbone of nucleic acids: a molecular dynamics study. J Biomol Struct Dyn. 2019;1:1-11.

32. van Dijk M, Bonvin AM. 3D-DART: a DNA structure modelling server. Nucleic Acids Res. 2009;37(suppl_2):W235-9.

33. Roberts VA, Pique ME, Lindsey S, Perez MS, Thompson EE, Ten Eyck LF: DOT 2.0. 1 User Guide. 2013

34. Bates D, Mächler M, Bolker B, Walker S: Fitting linear mixed-effects models using Ime4. arXiv preprint. arXiv:14065823. 2014.

35. Arnhold $\mathrm{E}$. Package in the $\mathrm{R}$ environment for analysis of variance and complementary analyses. Braz J Vet Res Anim Sci. 2013;50(6):488-92.

36. Ehret G: Genes for Preeclampsia: An Opportunity for Blood Pressure Genomics. In.: Am Heart Assoc; 2018.

37. Oudejans CB, van Dijk M, Oosterkamp M, Lachmeijer A, Blankenstein MA. Genetics of preeclampsia: paradigm shifts. Hum Genet. 2007;120(5):607-12

38. Yong HE, Murthi P, Brennecke SP, Moses EK: Genetic approaches in preeclampsia. In: Preeclampsia. edn.: Springer; 2018: 53-72.

39. Aggarwal PK, Jain V, Jha V. Endothelial nitric oxide synthase, angiotensinconverting enzyme and angiotensinogen gene polymorphisms in hypertensive disorders of pregnancy. Hypertens Res. 2010;33(5):473-7.

40. Stamilio DM, Sehdev HM, Morgan MA, Propert K, Macones GA. Can antenatal clinical and biochemical markers predict the development of severe preeclampsia? Am J Obstet Gynecol. 2000;182(3):589-94.

41. Duckitt K, Harrington D. Risk factors for pre-eclampsia at antenatal booking: systematic review of controlled studies. BMJ. 2005:330(7491):565.

42. Abalos E, Cuesta C, Grosso AL, Chou D, Say L. Global and regional estimates of preeclampsia and eclampsia: a systematic review. Eur J Obstetr Gynecol Reprod Biol. 2013;170(1):1-7.

43. Thangaratinam S, Langenveld J, Mol BW, Khan KS. Prediction and primary prevention of pre-eclampsia. Best Pract Res Clin Obstet Gynaecol. 2011;25(4):419-33.

44. Var A, Yildirim Y, Onur E, Kuscu NK, Uyanik BS, Goktalay K, Guvenc Y. Endothelial dysfunction in preeclampsia. Gynecol Obstet Invest. 2003:56(4):221-4.

45. Bernardi F, Constantino L, Machado R, Petronilho F, Dal-Pizzol F. Plasma nitric oxide, endothelin-1, arginase and superoxide dismutase in preeclamptic women. J Obst Gynaecol Res. 2008;34(6):957-63.

46. Bernardi FC, Vuolo F, Petronilho F, Michels M, Ritter C, Dal-Pizzol F. Plasma nitric oxide, endothelin-1, arginase and superoxide dismutase in the plasma and placentae from preeclamptic patients. An Acad Bras Ciênc. 2015:87(2):713-9.

47. Rassaf T, Ferdinandy P, Schulz R. Nitrite in organ protection. Br J Pharmacol. 2014:171(1):1-11.

48. Csonka C, Páli T, Bencsik P, Görbe A, Ferdinandy P, Csont T. Measurement of NO in biological samples. Br J Pharmacol. 2015;172(6):1620-32.

49. Buhimschi I, Yallampalli C, Chwalisz K, Garfield RE. Pre-eclampsia-like conditions produced by nitric oxide inhibition: effects of $\mathrm{L}$-arginine, $\mathrm{D}$-arginine and steroid hormones. Human Reproduction. 1995;10(10):2723-30.

50. Moncada S, Higgs A. The L-arginine-nitric oxide pathway. N Engl J Med. 1993;329(27):2002-12.

51. Persu A, Stoenoiu MS, Messiaen T, Davila S, Robino C, El-Khattabi O, Mourad M, Horie S, Feron O, Balligand J-L. Modifier effect of ENOS in autosomal dominant polycystic kidney disease. Hum Mol Genet. 2002:11(3):229-41. 
52. Tesauro M, Thompson W, Rogliani P, Qi L, Chaudhary P, Moss J. Intracellular processing of endothelial nitric oxide synthase isoforms associated with differences in severity of cardiopulmonary diseases: cleavage of proteins with aspartate vs. glutamate at position 298. Proc Natl Acad Sci. 2000;97(6):2832-5.

53. Ozturk E, Balat O, Pehlivan S, Ugur MG, Sever T. Genetic variation of myeloperoxidase gene contributes to preeclampsia: a preliminary association study in Turkish population. Hypertens Pregnancy. 2011;30(4):377-83.

54. Chen L-K, Huang C-H, Yeh H-M, Lee C-N, Shyu M-K, Hsieh F-J, Lai L-P, Sun W-Z. Polymorphisms in the endothelial nitric oxide synthase gene may be protective against preeclampsia in a Chinese population. Reprod Sci. 2007;14(2):175-81.

55. Sandrim VC, Palei AC, Metzger IF, Cavalli RC, Duarte G, Tanus-Santos JE. Interethnic differences in ADMA concentrations and negative association with nitric oxide formation in preeclampsia. Clin Chim Acta. 2010;411(19):1457-60.

56. Sandrim VC, Palei AC, Sertorio JT, Cavalli RC, Duarte G, Tanus-Santos JE. Effects of eNOS polymorphisms on nitric oxide formation in healthy pregnancy and in pre-eclampsia. Mol Hum Reprod. 2010;16(7):506-10.

57. Kim YJ, Park BH, Park H, Jung S-C, Pang M-G, Ryu H-M, Lee K-S, Eom S-M, Park H-Y. No association of the genetic polymorphisms of endothelial nitric oxide synthase, dimethylarginine dimethylaminohydrolase, and vascular endothelial growth factor with preeclampsia in Korean populations. Twin Res Hum Genet. 2008;11(1):77-83.

58. Nakayama M, Yoshimura M, Sakamoto T, Abe K, Yamamuro M, Shono M, Suzuki S, Nishijima T, Miyamoto Y, Saito Y. A- 786T > C polymorphism in the endothelial nitric oxide synthase gene reduces serum nitrite/nitrate levels from the heart due to an intracoronary injection of acetylcholine. Pharmacogenet Genomics. 2006;16(5):339-45.

59. Dosenko1 11/2 VE, Zagoriy VY, Haytovich NV, Gordok OA, Moibenko AA: Allelic polymorphism of endothelial NO-synthase gene and its functional manifestations. 2006.

60. Senthil D, Raveendran M, Shen YH, Utama B, Dudley D, Wang J, Wang XL. Genotype-dependent expression of endothelial nitric oxide synthase (eNOS) and its regulatory proteins in cultured endothelial cells. DNA Cell Biol. 2005;24(4):218-24.

61. Sandrim VC, Palei A, Luizon M, Izidoro-Toledo T. eNOS haplotypes affect the responsiveness to antihypertensive therapy in preeclampsia but not in gestational hypertension. Pharmacogenomics J. 2010;10(1):40-5.

\section{Publisher's Note}

Springer Nature remains neutral with regard to jurisdictional claims in published maps and institutional affiliations.
Ready to submit your research? Choose BMC and benefit from:

- fast, convenient online submission

- thorough peer review by experienced researchers in your field

- rapid publication on acceptance

- support for research data, including large and complex data types

- gold Open Access which fosters wider collaboration and increased citations

- maximum visibility for your research: over 100M website views per year

At BMC, research is always in progress.

Learn more biomedcentral.com/submissions 